\title{
Customers' Satisfaction on Campus Related Delivery Services
}

\author{
Rosanna D. Gonzales, Catherine N. Lumanta, Procerfina D. Vingua
}

PSU-Infanta Campus, Philippines

\begin{abstract}
Transactions between service providers and service seekers often end-up with various facial expressions which can be subjected to assessment and evaluation in the form of satisfaction feedback and be interpreted whether they are contented or claiming for more upon completing such. A satisfied customer will treasure the good experience and continually avail the products and services from an institution if the set criteria are met. Thus, the better services provided the higher probability for a company to stay in the service sector. This study focused in determining the degree of satisfaction on campus related delivery services provided to its customers. Results of the study showed that recipients of services are mostly female students in their adolescent stage who availed the top services from the offices of student services, registrar, library, and agriculture and college dean. The service units that received at par degree of satisfaction include planning, supply, registrar, medical, agriculture, student services, public relations, publications and information, library, research, physical plant facilities, gender-development and management-information system. The customers are very highly satisfied on the staff attitude of the campus and that their expectations along end result, convenience, timeliness and access often exceed their expectations. This implies that the campus related delivery service providers are customer-focused since they are able to provide and satisfy the needed and expected services as well as products stipulated in their respective units which are contributory to the attainment of the campus goal.
\end{abstract}

Keywords - campus, customers, related delivery services, satisfaction, Philippines.

\section{INTRODUCTION}

Today's industry and market scenario is full of competition, in fact; academic service institutions are never exempted in this situation. With competition, an improved and a more developed products and enhanced service quality are looked forward. From this standpoint, customers will be considered as the real winners since they will serve as one of the determining factors if the business will succeed or not (Biesok\&Wyrod-Wrobel, 2011). Higher education institutions (HEIs) oftentimes entertain queries from individuals or group of individuals like students, parents, alumni, community and stakeholders. Said individuals are categorized as customers and usually they demand answers with prescribed time and other measuring indicators for them to feel happy and satisfied upon completion of the requested service or product from a particular service unit (Weerasinghe, et.al. 2017).Conducting a study on customer feedback is an avenue in order to identify and determine one's strengths and weaknesses that may serve as a benchmark in understanding the areas that may need an intervention so as to serve better the service-seekers.

State Universities and Colleges (SUCs) play a vital role in providing quality educational services on various academic aspects of teaching-learning to achieve its intended vision, mission, goals and program objectives. According to Majeed et.al. as cited by Saif (2014) it is how business organizations operationalize its philosophy and how it addresses the demands of its administration by bringing about the desired change that may promote significant impact to the people that it serves. They also stated that in the case of SUCs, quality may refer to the set of core values, strategic goals, characteristics, variables, attributes and dimensions that gear towards the attainment of expected activities and services that they should perform in order to satisfy their respective customers. On the other hand, Randall (2002) mentioned that quality in educational system are related to set of terms 
and conditions that are readily available to meet the pre-set standards by the institution for its beneficiaries like the students, parents, regulatory bodies, community folks, alumni, and among others. In the words of Abu Nabah (2004), the term quality refers to work performance approach wherein the concept of "methoquality" (Saif, 2014) is the essence, thus; promotes the presence of academic (instruction) and non-academic (non-instruction) aspects. Highlighting the non-academic aspects where most of the organizations experience short falls as revealed by research results is the so-called services along facilities (Sapri, et.al., 2009). Being a service-delivery institution nowadays is not as easy as we want it to be because of the several number of SUCs aiming to give the best quality of educational service to guarantee that their existence is really essential. Therefore, competition is unavoidable and it is the name of the game. With competition, customers will have the opportunity to select the best institution that can provide them the best quality of service that they need in order to become globally competitive in the ever and fast changing need of the $21^{\text {st }}$ century. Likewise, competition will continuously require the service delivery institutions to improve and provide the services that will meet the quality standards of SUCs in terms of its manpower (people), moment (time), materials (facilities/equipment) and methods (process) (Chandra et.al., 2018). It is then important to understand the who, what, when, where, what and how can an institution satisfy the services delivered to its customers. Understanding customers' satisfaction will be useful for SUCs to be able to identify their strengths, weaknesses, opportunities and threats (Rudge, 2014), hence; such study.

\section{OBJECTIVES OF THE STUDY}

This study described the performance on related delivery services of Pangasinan State University-Infanta Campus for the $1^{\text {st }}$ Semester of School Year 2018-2019. Specifically, it described the profile of the respondents from all service units in the campus, campus units where most of the customers availed services, degree of satisfaction of customers from various campus delivery service units, and; the overall degree of satisfaction of customers along timeliness, access, convenience, staff attitude as well as end result.

\section{RELATED STUDIES}

\section{Services in SUCs}

Services received from SUCs are diverse, they come in many forms and on the same manner they are common in terms of their primary objectives that is (i.e.) to provide in-depth knowledge, seek academic development, educate students, and coordinate to development demands (local, national, and international) for them to be able to cater the core services in instruction, research, extension and production, hence; substantial infrastructures are of high demand. Sophisticated and fully -equipped buildings are of great significance (Sapri et.al., 2009).

\section{Student Satisfaction}

Satisfaction is defined as anything that provides a person the state of being able to experience the feeling of completeness from the service or product received. This in turn means that expectations are satisfied by the performance delivered by a certain service area and or service delivery provider. It is cyclical in nature since whatever experience one is exposed to tendency is to embrace the experience and provide the same experience to others if not addressed appropriately. Other researchers believed that satisfaction encompasses issues of students' perception and experiences while earning their pre-service education. According to Hom as cited in the study of Hasan et.al. (2008), studies on most student satisfaction focused on the perspective of customer, researchers faced a problem of creating a standard definition for "student satisfaction" so a customer satisfaction theory was selected and modified in explaining the meaning of student satisfaction. With the current phenomena/scenario of higher education marketplace, William as cited by Hasa et.al. (2008) specified that the student have become "customer" because of the considerations that they are fee payers who can reasonably demand therefore their views should be heard and acted upon.

\section{Determinants and Backgrounds of Consumers' Satisfaction}

In the world of competition, service delivery organizations need to be kept abreast on recent trends on the determinants and backgrounds of consumers' satisfaction. Consumers are also known as the customers, however; vary in terms of category. In educational environment the customers are the students, parents, alumni and stakeholders who have set of expectations from service delivery areas (instruction, research, extension, production) and providers (teachers, registrar, accountant, librarians, student services and the 
like). It is then imperative for every organization to give enough attention and focus on these specified determinants since one's satisfaction is geared towards the perceived services handed to them (Farahmandian et.al., 2013). The quality of services received by the customers may come in many forms and on the same manner based significantly on the perception of the receiver. If one will be able to provide the requested service on time, the customer may become fully satisfied, while others are after the availability of the service or materials needed. On the other hand, others may prefer the characteristics of the service providers over the other determinants. Most of the researches conducted now is on customer satisfaction due to its necessity which means that dissatisfaction may tend for the customers to withdraw their loyalty from the organization and look for an alternative or for them to transfer to better kind of environment. Worst is for them not to encourage other people to patronize one's product or services that may cause bankruptcy or discontinuity of the organizations' operation which will mean a big frustration on the part of those who are in the academic sector.

\section{Dimensions of Perceived Service Quality}

According to Soutar and McNeil as cited by Farahmandian et.al. (2013), service quality based on the perception of the customers like the students come in two kinds namely: the academic and the non-academic. Some of the cited studies by Farahmandian et.al (2013) includes library facilities, level of curriculum, leisure facilities, computing facilities, availability of academic personnel and quality of teaching (Athiyaman), likewise; with the 14 dimensions which are the library facilities, travel agency, housing services, occupation services, university bookshop, advisory services, health services, financial assistance, and involvement of students in course contents, work expertise and computing facilities (Hill). One interesting result that was indicated in the study was on the relationship of the student satisfaction on the services receives from the counseling staff, faculty and classes (Hammed and Amjad) wherein the study intensely recommends that the failure and success of students in every higher educational institution is related to the level of satisfaction and dissatisfaction, because of the perception from the customers (students) that higher educational quality brings higher learning chances as claimed by Aldridge and Rowley (Farahmandian et.al. 2013).

\section{THEORETICAL MODEL}

The study considered"degree of customers' satisfaction" as the dependent variable in relation to the five perceived service quality factors (timeliness, access, convenience, staff attitude, end result) as independent variables.

\section{METHODOLOGY}

The quantitative research method and descriptive research design were used in this study wherein the main instrument was the university questionnaire framed to be administered to all service units in the campus known as the "customer satisfaction survey" which are requested to be filled up by the customers after availing services or products. Convenience sampling was utilized wherein a total of 172 respondents was identified. The survey composed of three (3) parts: Part I on Profile of the respondents (department visited, age, sex and client category) while Part II includes the indicators on timeliness, access, convenience, staff attitude and end result, and; Part III asked for the recommendations or suggestions from the customers to improve the quality of the services. The results of the study were analyzed with the use of an appropriate statistical tool such as frequency counts, percentage, weighted mean and rank. The computed weighted mean was interpreted using a mean range scale with verbal description as: 4.50-5.00 - Very Highly Satisfied (VHS); 3.50-4.49 - Highly Satisfied (HS); 2.50-3.49 -Satisfied (S); 1.50-2.49 - Less Satisfied (LeS), and: 1.00-1.49 - Least Satisfied (LeaS).

\section{RESULTS AND DISCUSSION}

\section{Profile of Respondents}

There are more than $50 \%$ of the respondents are female compared to male with 44.8 percent. It can be associated to the higher number of female enrollees over males. However, Philippine population-wise and to date, data reveals that males is composed $50.1 \%$ of the country's total population while $44.9 \%$ are females (https://countrymeters. info/en/Philippines) while in terms of customers' category, the bulk are categorized as students with $78.5 \%$, followed by alumni (7.6 percent), faculty (5.2 percent), non-teaching (4.7 percent), community (2.8 percent) and supplier with 1.2 percent. This indicates that the campus service-seekers are those who are regularly attending the school days and are the direct beneficiaries of services and products since the study is conducted in an academic-institution whose expected main 
respondents are students, teaching and non-teaching staff who are known as the primary customers because based from Pereira and Da Silva's (2003) study, customers may come in 3 forms (primary, secondary and tertiary). On the other hand, the age range of the respondents availing the campus related delivery services in from 15 to 20 which is identified as under the "adolescence" development stage of life wherein it is described as the "period of storm and stress" (Sharma, n.d.). On the other hand, the service unit most availed by the respondents are student services (9.9 percent), registrar (8.7 percent) and library (7.6 percent). This is in conformity with the student basic service need which is on the attainment of emotional stability since they are in their adolescent stage facing complex dogmas (Bindu, 2016).Further, the least availed are chemistry laboratory, planning and practice teaching. This may imply that these service units are not within the immediate needs of the customers because practice teaching is often offered at the second semester and it entails less participation on their side.

\section{Degree of Satisfaction}

The degree of satisfaction on campus related delivery services of various units is shown in table 1.

Table 1. Degree of Satisfaction from Service Units

\begin{tabular}{lll}
\hline Service Units & Weighted Mean & Verbal Description \\
\hline Planning & 5 & Very Highly Satisfied \\
Supply & 4.83 & Very Highly Satisfied \\
Registrar & 4.77 & Very Highly Satisfied \\
Medical & 4.77 & Very Highly Satisfied \\
Agriculture Dept. & 4.76 & Very Highly Satisfied \\
Student Services & 4.68 & Very Highly Satisfied \\
PRPIO & 4.66 & Very Highly Satisfied \\
Library & 4.63 & Very Highly Satisfied \\
Research & 4.55 & Very Highly Satisfied \\
Physical Plant \& Facilities & 4.54 & Very Highly Satisfied \\
GAD & 4.52 & Very Highly Satisfied \\
MIS & 4.51 & Very Highly Satisfied \\
Admin & 4.44 & Very Satisfied \\
College Dean & 4.22 & Very Satisfied \\
Extension & 4.14 & Very Satisfied \\
Food Laboratory & 4.14 & Very Satisfied \\
Cultural & 4.08 & Very Satisfied \\
Sports & 4.06 & Very Satisfied \\
Education Dept. & 4.01 & Very Satisfied \\
Chemistry Lab & 3.78 & Very Satisfied \\
Practice Teaching & 3.66 & Very Satisfied \\
\hline Overall Weighted Mean & $\mathbf{4 . 4 5}$ & Very Satisfied \\
\hline
\end{tabular}

The campus gained an overall mean of 4.45 which means that the customers are "very satisfied" with the kind and quality of service that they received across the service units. Further, they are "very highly satisfied" on the services from planning, supply, registrar, medical, agriculture department, student services, PRPIO, library, research, physical \& plant facilities, GAD and MIS while they are "very satisfied" along the services received from admin, college dean, extension, food laboratory, cultural, sports, education department, chemistry laboratory and practice teaching. This implies that the campus related delivery services are able to meet satisfactorily the demands of their respective clients.

Table presents the respondents' degree of satisfaction along selected indicators (timeliness, access, convenience, staff attitude and end result. 
Table 2. Degree of Respondents Satisfaction along Selected Indicators

\begin{tabular}{|c|c|c|c|}
\hline Indicators & Mean & Verbal Description & Rank \\
\hline $\begin{array}{l}\text { Staff Convenience } \\
\text { a. The staff providers were courteous and polite in } \\
\text { providing the requested service. } \\
\text { b. The staff providers are friendly to the clients. }\end{array}$ & $\begin{array}{l}\mathbf{4 . 5 0} \\
4.48 \\
4.52\end{array}$ & Very Highly Satisfied & 1 \\
\hline $\begin{array}{l}\text { End Result } \\
\text { a. The requested output on the services availed were } \\
\text { complete. } \\
\text { b. The requested output on the services availed were of } \\
\text { standard quality. }\end{array}$ & $\begin{array}{l}4.40 \\
4.37 \\
4.44\end{array}$ & Highly Satisfied & 2 \\
\hline $\begin{array}{l}\text { Convenience } \\
\text { a. The services requested were obtained with minimum } \\
\text { inconvenience. } \\
\text { b. The services were made available with ease and } \\
\text { comfort. }\end{array}$ & $\begin{array}{r}4.39 \\
4.34 \\
4.44\end{array}$ & Highly Satisfied & 3 \\
\hline $\begin{array}{l}\text { Timeliness } \\
\text { a. The services provided by the office were delivered } \\
\text { within the minimum waiting time. } \\
\text { b. The services provided by the office were quick. }\end{array}$ & $\begin{array}{l}4.38 \\
4.37 \\
4.40\end{array}$ & Highly Satisfied & 4 \\
\hline $\begin{array}{l}\text { Access } \\
\text { a. The services requested were made available as per } \\
\text { request. } \\
\text { b. The services needed from the staff were readily } \\
\text { available. }\end{array}$ & $\begin{array}{r}4.36 \\
4.34 \\
4.38 \\
\end{array}$ & Highly Satisfied & 5 \\
\hline
\end{tabular}

Among the five selected indicators included in the campus related delivery services, results reveal that the customers are very highly satisfied on the staff attitude with 4.50 weighted mean wherein they are described as courteous, polite and friendly in providing the requested service. Likewise, the customers are very satisfied on end result (services are complete and of standard quality), convenience (services are obtained with minimum inconvenience and availing such is with ease and comfort), timeliness (services are delivered within minimum waiting time and are quickly delivered) and access (services requested are available and the staff are readily available).

\section{CONCLUSION AND RECOMMENDATIONS}

PSU-Infanta campus respondents are females, dominated by students in their adolescence stage who usually avail the student services, registrar and library services. The service units that top on the degree of customers' satisfaction are planning, medical and registrar. Along the campus related service delivery indicators, the staff attitude is highly appreciated by the customers. Sustain the degree of satisfaction of the indicators that excellently met the customers' standards and on the same manner strengthen the delivery service of the campus units that satisfactorily met the customers' expectations. Continuous study is recommended by using a customized questionnaire applicable to every service unit so as to have a more objective result on the services availed by the customers.

\section{REFERENCES}

[1] Abu Nabah ,Abdulaziz (2004). Studies in University Administration Modernization. Amman: Warraq Publishing and Distribution.

[2] Biesok, Grzegorz\&Wyród-Wróbel, Jolanta. (2011). Customer satisfaction - Meaning and methods of measuring. 
https://www.researchgate.net/publication/318013354_Custome r_satisfaction_Meaning_and_methods_of_measuring/citation/d ownload

[3] Bindu. 2016. A Comparative Study of Emotional Stability of Adolescent Students. Scholarly Research Journal for International Studies. MAY-JUNE 2016, Vol-3/24 http://oaji.net/articles/2016/1174-1468665728.pdf

[4] Chandra, T., Ng, M., Chandra, S. \&Priyono. (2018). The effect of service quality on student satisfaction and student loyalty: an empirical study. Journal of Social Studies Education Research Sosyal Bilgiler Eğitimi Araştırmaları Dergisi 2018:9 (3), 109-131

[5] Farahmandian, S., Minavand, H. \&Afsfardost, M. (2013). Perceived service quality and student satisfaction in higher education. IOSR Journal of Business and Management (IOSRJBM) e-ISSN: 2278-487X, p-ISSN: 2319-7668. Volume 12, Issue 4 (Jul. - Aug. 2013), PP 65-74 www.iosrjournals.org

[6] Pereira, M. \& Da Silva, M. 2003. A Key Question for Higher Education: Who are the customers? Proceedings of the 31st Annual Conference of the Production and Operations Management Society, POM-2003, April, 4-7, 2003, Atlanta, GE https://pomsmeetings.org/ConfProceedings/001/Papers/SOM19.3.pdf

[7] Randall, John (2002). Quality Assurance: Meeting the Needs of the User. Higher Education Quarterly Journal, Vol. 56, No. 2. PP:188-203.

[8] Rudge, N. (2014). Examining student satisfaction with the student services. Center at a Local Community College" (2014). Counselor Education Master's Theses. 157. http://digitalcommons.brockport.edu/edc_theses/157

[9] Saif, N. (2014). The effect of service quality on student satisfaction: a field study for health services administration students. International Journal of Humanities and Social Science Vol. 4, No. 8; June 2014

[10] Sapri, M., Skudai, J. \& Finch, E. (2009). Factors that influence student's level of Satisfaction with regards to higher educational facilities. Malaysian Journal of Real Estate Volume 4 No 12009

[11] Sharma, A. n.d. Stages of Development of Psychology of People at Different Ages from Infancy to Old Age. http://www.psychologydiscussion.net/psychology/stages-ofdevelopment-of-psychology-of-people-at-different-ages-frominfancy-to-old-age/732

[12] Weerasinghe, IM S, Lalitha, R. \& Fernando, S. 2017. Students' Satisfaction in Higher Education Literature Review. American Journal of Educational Research. 2017, 5(5), 533539. DOI: 10.12691/education-5-5-9 http://pubs.sciepub.com/education/5/5/9/index.html 